\title{
TOXICOLOGICAL PROFILE AND BLOOD ALCOHOL CONTENT OF SUICIDE VICTIMS IN THE FAR WEST OF SANTA CATARINA
}

\section{Chielle EO}

Doctor and Master of Pharmaceutical Sciences for Universidade Federal de Santa Maria; Teacher of Laboratory of Clinical Biochemistry - Department of Life Sciences - Universidade do Oeste de Santa Catarina of São Miguel do Oeste; Rua Oiapoc, 211, Agostini, 89900-000, São Miguel do Oeste, Santa Catarina, Brasil; eduardochielle@ yahoo.com.br; https://orcid.org/0000-0003-3566-1258

\section{Genz F}

Graduating in Pharmacy from the Universidade do Oeste de Santa Catarina of São Miguel do Oeste; fagnergenz@gmail.com; https://orcid.org/0000-0001-6424-319X

\section{Petter A}

Graduating in Psychology from the Universidade do Oeste de Santa Catarina of São Miguel do Oeste; abel.petter@hotmail.com; https://orcid.org/0000-0003-4765-7520

Abstract: Suicide has been a subject of increasing concern and the toxicological and blood alcohol investigate in these victims is little studied. This study investigated the toxicological and blood alcohol profile of suicide victims in 27 municipalities in the extreme west of Santa Catarina. Aggregate time series study, with a survey of epidemiological data and analysis of expert reports by the Medical Legal Institute of all fatal victims of suicide, registered in the period between 2012 to 2016. Results: Males, aged 50-59 years, were the main victims and the hanging the main suicide method. The months of February and November, Sundays and the time of 08:00 to 11:59 were the moments of greater occurrences. Elevated levels of alcohol were observed in $23.97 \%$ of the victims and the main drugs found were benzodiazepines and tricyclic antidepressants. The results obtained in this study reinforce the concern regarding cases of suicide and an association between alcohol/drug use and suicidal practices. The data provide subsidies for elaboration and implementation of preventive actions. Professionals should be alert to signs of suicide, so that specialized help becomes a possible option, and is instrumental in reducing the number of suicides.

Keywords: Alcohol. Drugs. Suicide. Victims. 


\section{INTRODUCTION}

From the nineteenth century, physician Philippe Pineal (1745-1826) was the first to consider the idea that suicidal thoughts and actions could be associated with mental disorders. This author introduced the idea that the suicidal person possesses moment of alienation/delusions which served as the basis for suicide to be considered part of a mental illness, ceasing to be a crime proper. ${ }^{1}$ Thus, since the 1990 s, suicide is approached as a problem the World Health Organization (WHO). ${ }^{2}$

Since 1960, Brazil has been undergoing an epidemiological transition, in which external causes of death are in the process of replacing infectious and parasitic diseases. The increase in suicide rates has contributed to this trend, which is the third cause of death due to external factors identified: homicide (36.4\%), traffic-related deaths (29.3\%) and suicide (6.8\%). Suicide cases have been rising significantly in recent years and are a problem for public health. ${ }^{3,4}$ Studies released by the WHO show that close to 800,000 people commit suicide every year. ${ }^{5}$ In addition, WHO points out that suicide-induced deaths have increased by $60 \%$ in the past 50 years. ${ }^{6}$

During the year 2016, 10.5 cases per 100,000 inhabitants were registered in the world, which corresponds to one suicide for every 40 seconds. ${ }^{5}$ In the year 2014 , on a world scale, suicide became the cause of $51.8 \%$ of intentional deaths, with homicides (36.9\%) and warlike conflicts (11.3\%) ahead. For the year 2020, the projection reaches 1.5 million suicides per 100,000 inhabitants. $^{7}$

In addition, there are an average of three to four suicides per 100,000 inhabitants in Brazil, the incidence being higher in men (four times higher when compared to women) and with increasing levels in the younger and more economically active population. ${ }^{8}$ The ratio between genders ranges from 3,0:1 to 7,5:1, with the exception of India and China, where the ratio of men to women is $1,3: 1$ and 0,9:1 respectively. ${ }^{9}$

The WHO proposes a classification that organizes suicide rates at low (less than 5 cases per 100,000 population), average (from 5 to 15 cases per 100,000 population) and high (from 15 to 30 cases per 100,000 population). In this sense, according to WHO information, Brazil is classified as an average suicide rate, with a rate of 5.8 cases per 100,000 inhabitants in 2016, considering regional variations. ${ }^{10,11}$ 
The Ministry of Health shows that the South region has the highest coefficients of suicide mortality in Brazil. ${ }^{10}$ According to DATASUS data, the suicide rate for the southern region is 8.5 cases per 100,000 inhabitants. As an integral part of the southern region of Brazil, the state of Santa Catarina presents suicide mortality rates around 7 per 100,000 inhabitants. ${ }^{11}$ This coefficient represents almost double the national average, which is around 4,5 thousand. There are also big differences when analyzing suicide rates from different states. ${ }^{12}$

In Santa Catarina, as well as in the rest of the country, cases of death due to suicide present significant regional variations. The State Department of Health concluded that suicide mortality rates in the extreme western region of Sata Catarina were around 11 per 100,000 inhabitants in 2001, higher than the homicide rates in the region. ${ }^{13}$

Suicide rates across the world vary according to regional, socio-environmental and cultural characteristics, as well as suicide deaths. ${ }^{14,15}$ In addition, it is known that the psychological and social impact caused by suicide in a family and in society is of enormous proportions. On average, a single suicide affects at least six other people. However, if a suicide occurs in a school or a company, for example, the impact generated is greater, involving hundreds of people. ${ }^{16}$

Suicide can be related to various factors of encouragement, such as: unemployment, poverty, domestic problems, lack of social support, legal and financial difficulties, low literacy, strong intention and previous suicide attempts, family history, stress, illnesses chronics and psychiatrics and abuse of alcohol and drugs. ${ }^{17-21}$

However, the toxicological investigation of other drugs and alcoholism that alter the behavior of individuals with suicidal potential is still poorly studied, especially in developing countries such as Brazil. Thus, in the face of the scarcity of recent studies concerning suicide in the state of Santa Catarina, this study sought, through a partnership with the General Institute of Expertise (IGP) in the IML - Legal Medical Institute, to analyze expert reports of the toxicological profile and epidemiological data of victims of suicide in the 27 municipalities of the Far West of Santa Catarina, to create subsidies that serve as an aid in the construction of public policies that prevent the problem. 


\section{MATERIALS AND METHODS}

A aggregate temporal series study was performed with a survey of documentary data in order to obtain epidemiological data through the results of the technical expert reports of all fatal victims of suicide recorded between 2012 and 2016 at the Legal Medical Institute (IML) of São Miguel do Oeste covering 27 municipalities in the Far West of Santa Catarina. For the development of this research was carried out in a documented partnership with the IML unit of São Miguel do Oeste. The study was approved by the Ethics Committee of the University of Western Santa Catarina $\left(n^{\circ} 2,189,638\right)$.

Of all the fatal victims of suicide, blood and urine samples are collected and analyzed by the Institute of Forensic Analysis of the State of Santa Catarina and the expert's report is issued. This expert's report was analyzed and the variables age, sex, type of suicide, place of residence, month, day and time of occurrence, alcoholic dosage and presence of drugs such as cannabinoids, cocaine, methamphetamine, methadone, benzodiazepines, opiates, barbiturates, amphetamines, Methylene dioxy methamphetamine (MDMA) and tricyclic antidepressants were checked.

The alcoholic dosage was performed by gas chromatography with "Head Space" sampling under the following conditions: Trace GC 1310 and Triplus RSH; FID detector Flame ionization; Stationary phase, Rtx - BAC Plus column 1: $30 \mathrm{~m} \times 0.32 \mathrm{~mm} \times 1.80 \mu \mathrm{m}$; Mobile phase, Helium 145kPa; Temperatures, injector $230{ }^{\circ} \mathrm{C}$, column $60{ }^{\circ} \mathrm{C}$ (isothermal) and detector $250^{\circ} \mathrm{C}$.

The toxicological analysis was performed in a quantitative competitive chemiluminescent enzyme immunoassay in the biochip analysis, Evidence Investigator TM - Ramdox, with the in vitro test kit Drugs of Abuse I Urine Plus.

The data obtained were treated in Microsoft Excel 2000 programs (Microsoft Corp., United States) and presented in the form of figures.

\section{RESULTS}

In the period from January 2012 to December 2016, 146 people were fatal victims of suicide in the Far West of Santa Catarina, being $82.19 \%$ male and $17.81 \%$ female. (Figure 
1A). The age group with the highest number of deaths was $50-59$ years $(23.97 \%)$, followed by $40-49$ years $(19.86 \%)$, and hanging $(86.99 \%)$ was the main form of suicide, as shown in Figures 1 ( $B$ and $C$ ).

A

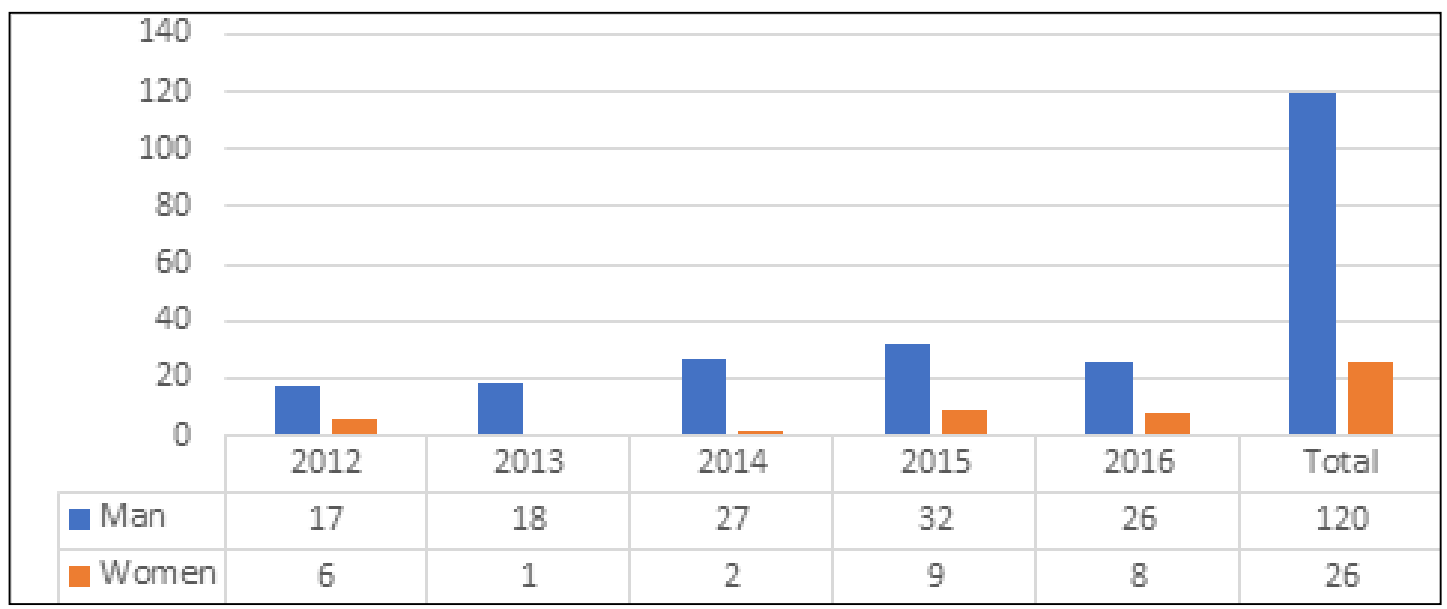

B

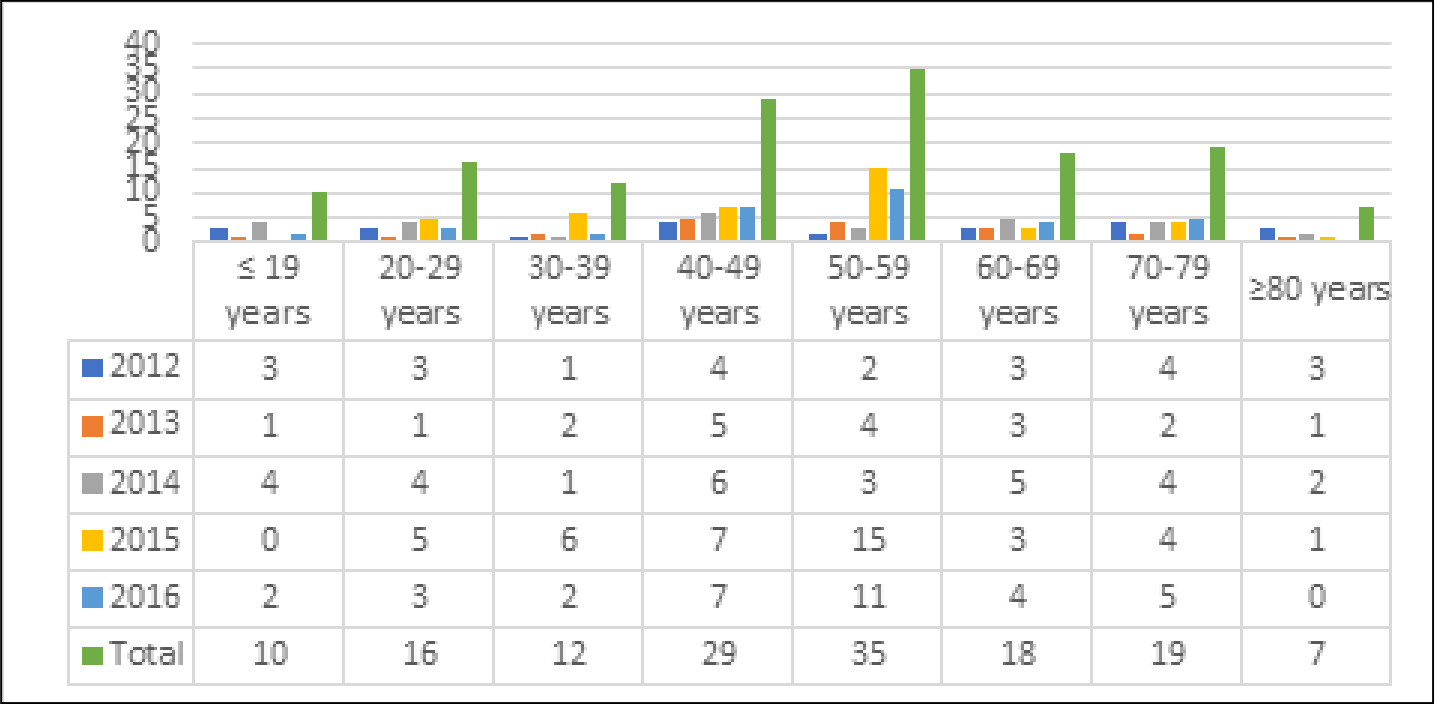


C

\begin{tabular}{|c|c|c|c|c|c|c|}
\hline \multicolumn{7}{|l|}{120} \\
\hline \multicolumn{7}{|l|}{100} \\
\hline \multicolumn{7}{|l|}{80} \\
\hline \multicolumn{7}{|l|}{60} \\
\hline \multicolumn{7}{|l|}{40} \\
\hline \multicolumn{7}{|l|}{20} \\
\hline 0 & 2012 & 2013 & 2014 & 2015 & - & L-1 \\
\hline EHanging & 10 & 17 & 26 & 36 & 30 & 127 \\
\hline E Gun shot & 3 & 2 & 1 & 5 & 2 & 13 \\
\hline Whitegun & 1 & 0 & 1 & 0 & 0 & 2 \\
\hline poisoning & 1 & 0 & 1 & 0 & 2 & 4 \\
\hline
\end{tabular}

Figure 1 - Distribution of deaths according to gender (A), age $(B)$ and suicide form (C) Source: IGP São Miguel do Oeste (2012 - 2016).

The months, days and times with the highest occurrence of deaths are presented in Figure $2 \mathrm{~A}, \mathrm{~B}$ and $\mathrm{C}$. The months with the highest number of victims were February and November (10.96\%), followed by March (10.27\%) and September (9.59\%). In relation to the days of the week, they did not present great variations, with Sunday $(17.81 \%)$ and Thursday $(17.12 \%)$ as the days of the week with the highest prevalence of deaths. In relation to the time of greatest occurrence of victims, it was found that from 08:00 to 11:59 was the time of greatest registration (26.03\%) and from 04:00 to 07:59 hours with fewer deaths (7.53\%).

A

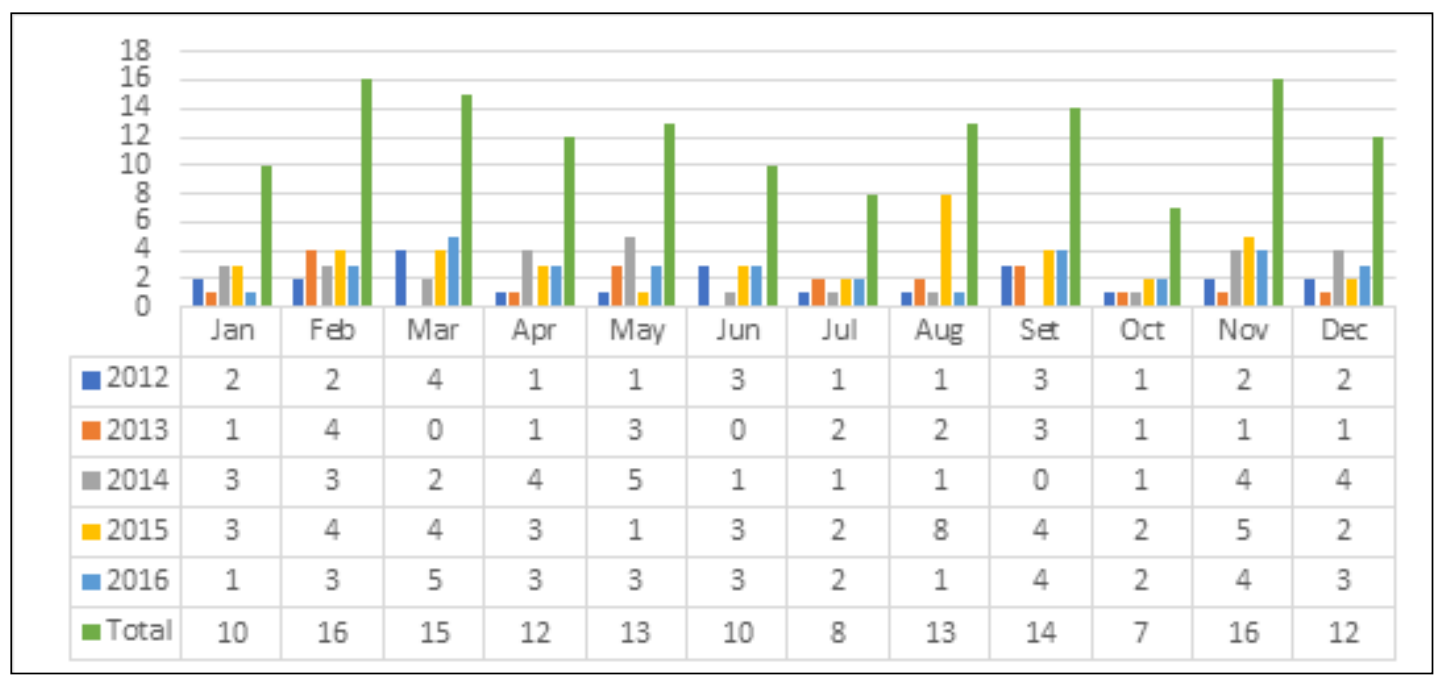


B

\begin{tabular}{|c|c|c|c|c|c|c|c|}
\hline \multicolumn{8}{|l|}{30} \\
\hline \multicolumn{8}{|l|}{25} \\
\hline \multicolumn{8}{|l|}{20} \\
\hline \multicolumn{8}{|l|}{15} \\
\hline 10 & & & & & & & \\
\hline \multicolumn{8}{|l|}{5} \\
\hline 0 & Monday & Tuesday & Wednesday & Thursday & Friday & Saturday & Sunday \\
\hline E 2012 & 2 & 1 & 4 & 6 & 4 & 1 & 5 \\
\hline$=2013$ & 1 & 5 & 2 & 4 & 1 & 2 & 4 \\
\hline 2014 & 1 & 3 & 7 & 5 & 5 & 3 & 5 \\
\hline$=2015$ & 8 & 6 & 3 & 7 & 5 & 5 & 7 \\
\hline =2016 & 10 & 3 & 5 & 3 & 7 & 1 & 5 \\
\hline - Total & 22 & 18 & 21 & 25 & 22 & 12 & 26 \\
\hline
\end{tabular}

C

\begin{tabular}{|c|c|c|c|c|c|c|c|}
\hline \multicolumn{8}{|l|}{$\begin{array}{l}40 \\
35\end{array}$} \\
\hline \multicolumn{8}{|l|}{30} \\
\hline \multicolumn{8}{|l|}{25} \\
\hline \multicolumn{8}{|l|}{20} \\
\hline \multicolumn{8}{|l|}{15} \\
\hline \multicolumn{8}{|l|}{10} \\
\hline 5 & & & & & & & \\
\hline 0 & $1=$ & 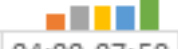 & & & 1日1 & al| & 烈 \\
\hline & $00: 00-03: 59$ & $04: 00-07: 59$ & $08: 00-11: 59$ & $12: 00-15: 59$ & $16: 00-19: 59$ & $20: 00-23: 59$ & Missed time \\
\hline [ 2012 & 5 & 0 & 5 & 5 & 5 & 3 & 0 \\
\hline = 2013 & 2 & 2 & 1 & 6 & 3 & 5 & 0 \\
\hline 2014 & 3 & 3 & 10 & 2 & 7 & 4 & 0 \\
\hline 2015 & 1 & 3 & 10 & 6 & 11 & 8 & 2 \\
\hline $\mathbf{n} 2016$ & 1 & 3 & 12 & 6 & 6 & 6 & 0 \\
\hline - Total & 12 & 11 & 38 & 25 & 32 & 26 & 2 \\
\hline
\end{tabular}

Figure 2 - Death distribution according to the month of the year (A), day of the week $(B)$ and time of occurrence (C)

Source: IGP São Miguel do Oeste (2012 - 2016).

Of the total number of victims analyzed, $75.34 \%$ did not present blood alcohol levels, however, it was observed that $23.97 \%$ presented levels significantly above the values allowed by Brazilian legislation. The victims in whom the presence of alcohol was detected above the amount allowed by the legislation were mostly male (97.14\%), compared to $2.86 \%$ female (Figure 3). About $28.57 \%$ of the victims were aged $40-49$ and 20\% were 50-59 years old (Figure 4A). The highest number of alcohol-related deaths 
occurred in February and December (14.29\%), followed by January, April and November (11.43\%) (Figure 4B). Sunday was the day with the highest prevalence of alcoholic victims, with $28.57 \%$, followed by Wednesday (22.86\%), as shown in Figure 4C. In addition to the presence of alcohol, in some fatalities, the presence of drugs was also observed, with the benzodiazepine class, especially Oxazepam and Alprazolam, and the class of antidepressants, especially Amitriptyline and Nortriptyline, the most commonly found drugs with $6.16 \%$ (Figure 5).

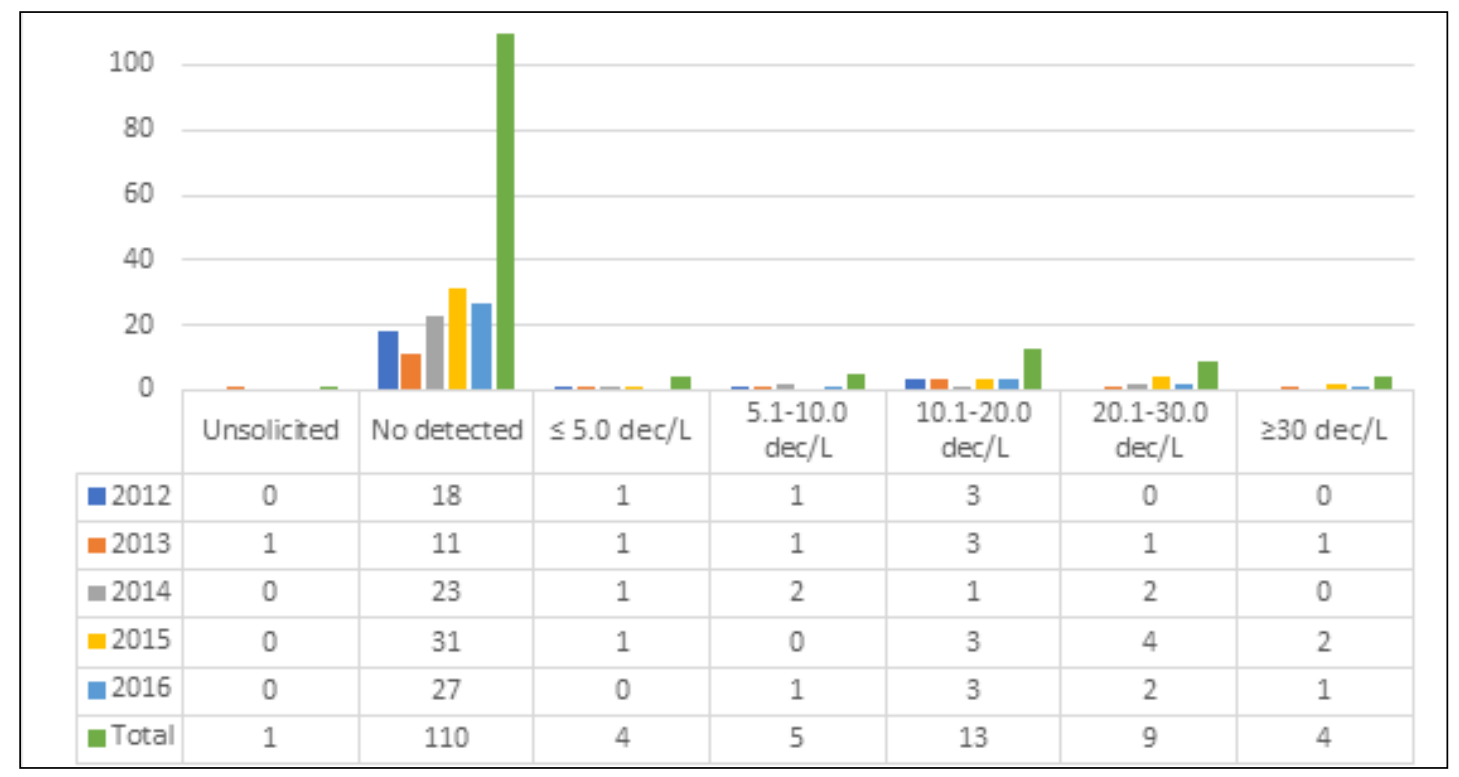

Figure 3 - Alcoholic concentration found in the suicide victims of the Far West of Santa Catarina Source: IGP São Miguel do Oeste (2012 - 2016).

A

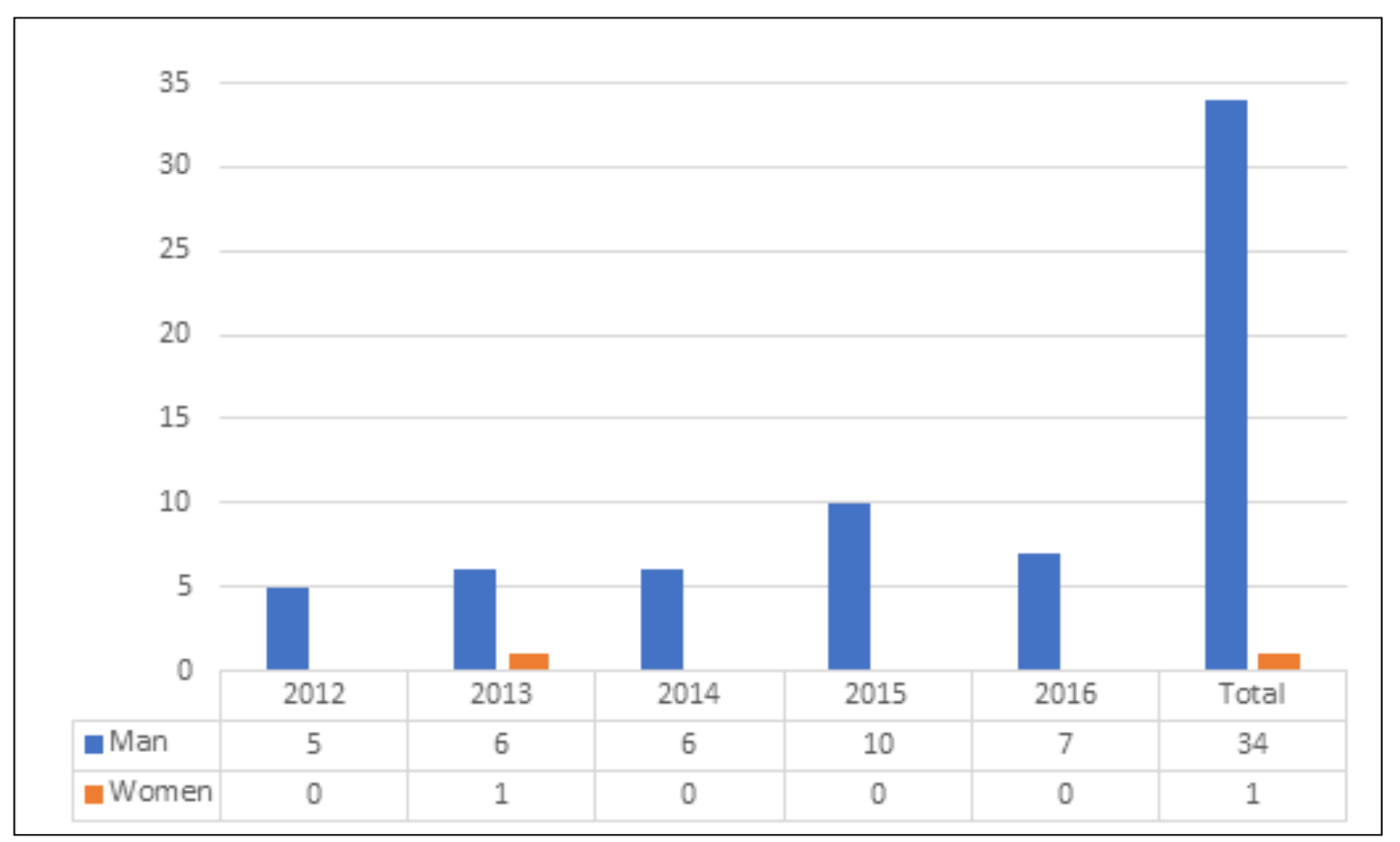


B

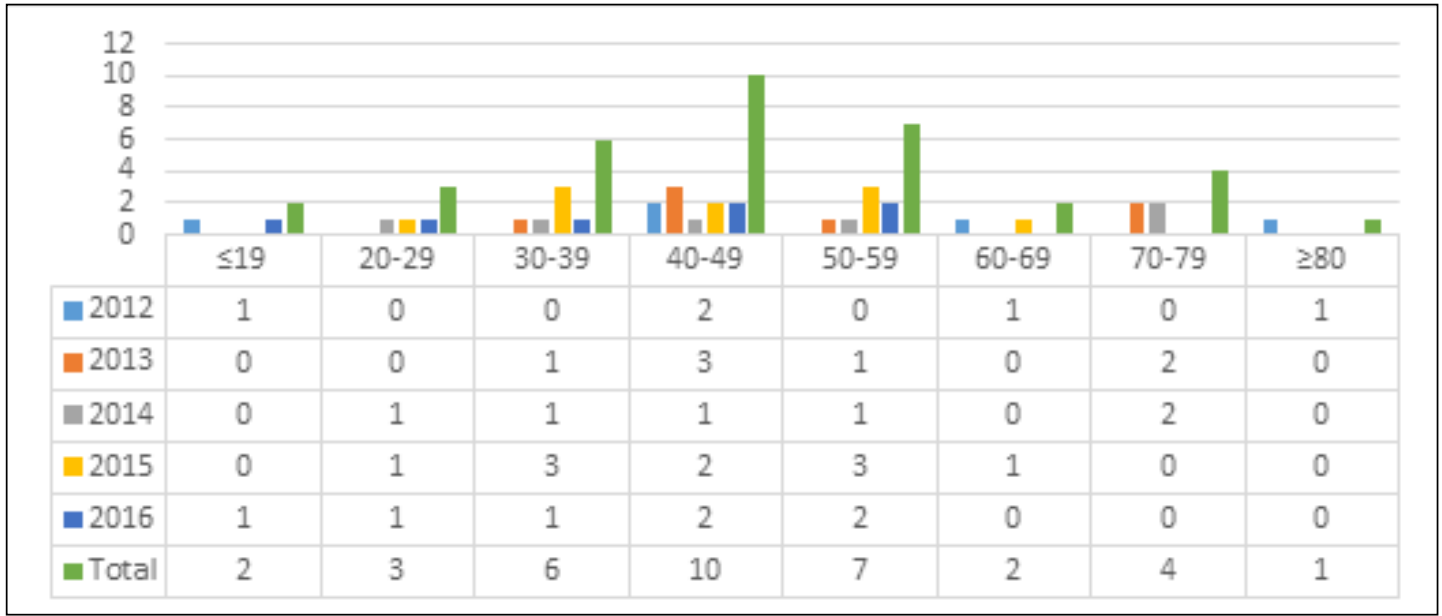

C

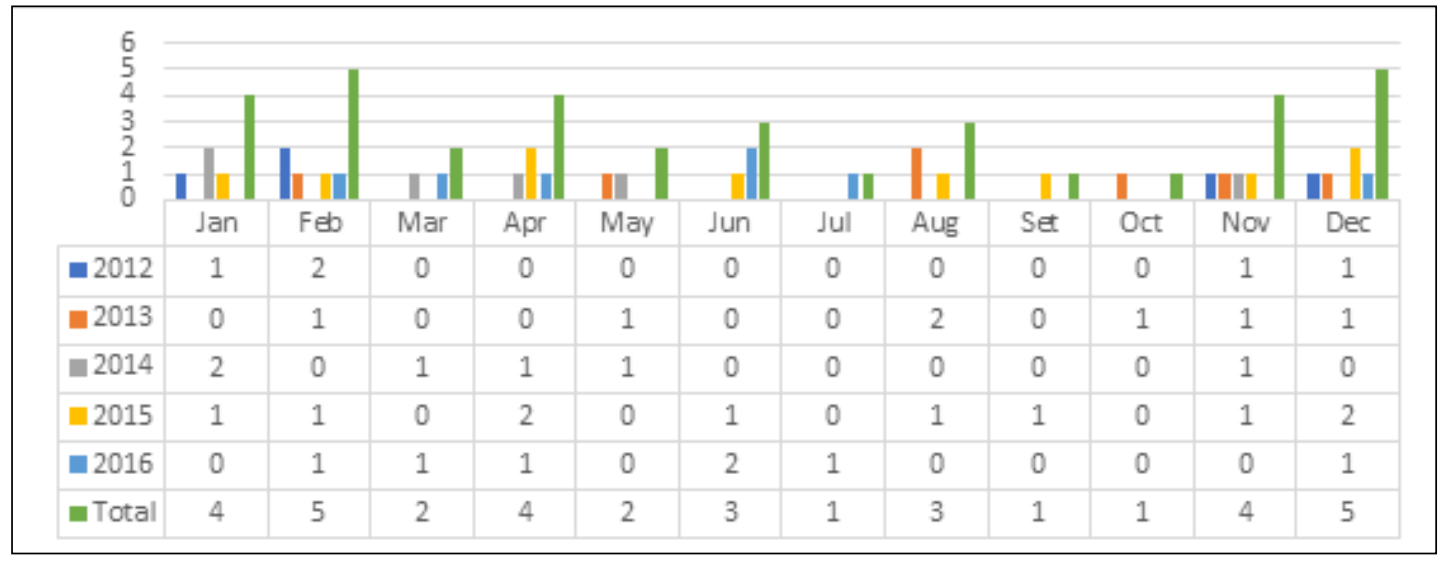

D

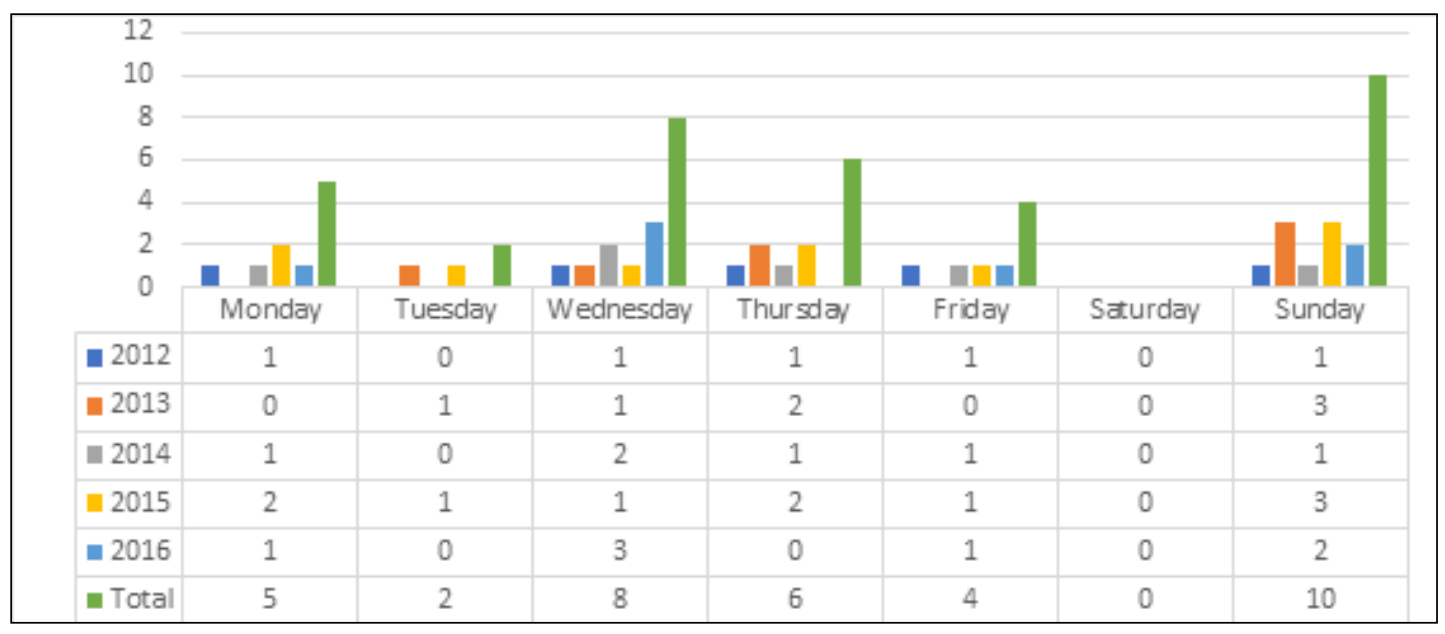

Figure 4 - Distribution of suicide victims from the Far West of Santa Catarina with presence of alcohol by sex $(A)$, age (B), month of the year (C), day of the week (D)

Source: IGP São Miguel do Oeste (2012 - 2016). 


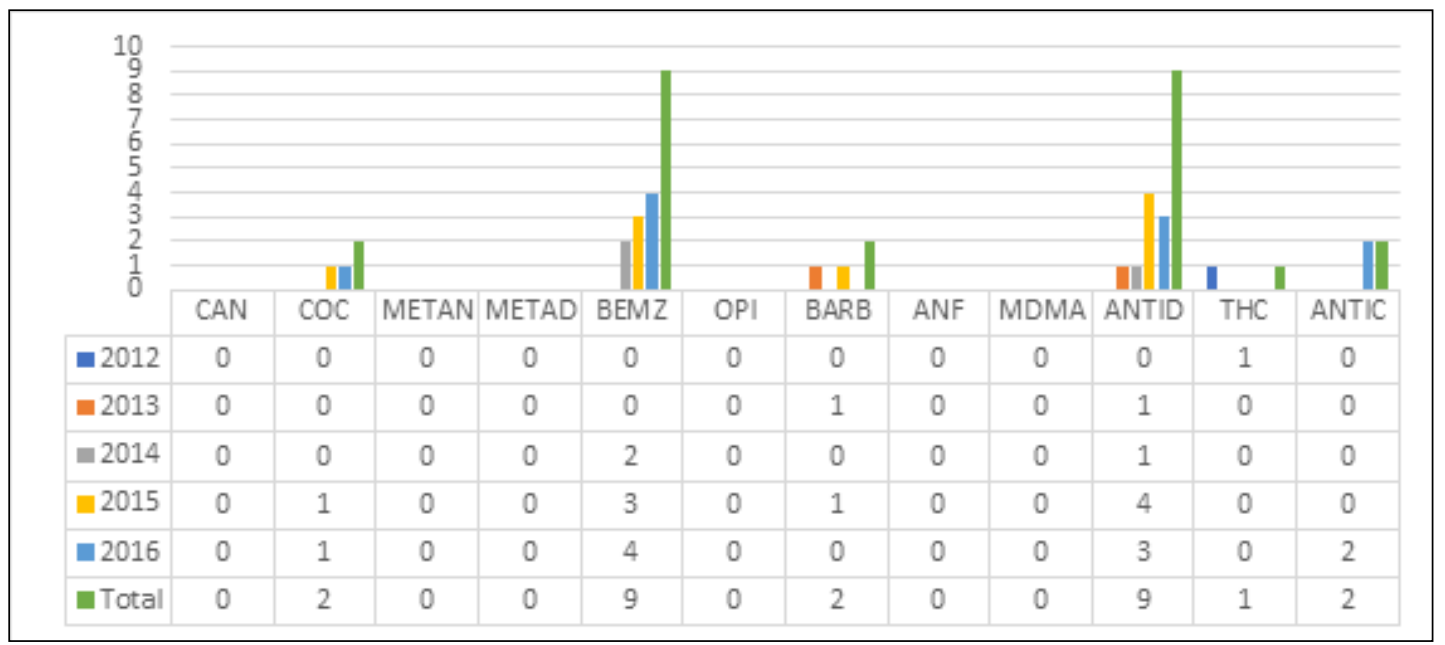

Figure 5 - Main drugs found in victims of suicide in the Far West of Santa Catarina Source: IGP São Miguel do Oeste (2012 - 2016).

Note: CAN: Cannabinoids; COC: Cocaine; METAN: Methamphetamine; METAD: Methadone; BENZ: Benzodiazepines; OPI: Opiates; BARB: Barbiturates; ANFE: Amphetamine; ANTID: Antidepressants; ANTIC: Anticholinergic.

\section{DISCUSSION}

This study described the toxicological profile and blood alcohol levels related to the sex, age, period, time and the forms found in cases of suicides consumed in the Far West of Santa Catarina. A total of 146 cases of suicide were analyzed during the years 2012 to 2016, in which the analysis of blood alcohol content and the toxicological profile were performed.

In relation to the continuous increase in suicide rates in recent years, this issue, in addition to being addressed as a public health problem, led in 2006 to the development of a suicide prevention manual for mental health professionals. Another advance would be the identification of risk factors, besides mental disorders, such as sex and age, ${ }^{1}$ helping to identify a suicidal potential.

In relation to the most vulnerable social groups, they were observed through several years of research on this phenomenon. In general, for example, most of the suicides analyzed in Barcelona (MG) occurred in adults, single and male, with hanging being the preference for both sexes. ${ }^{13} \mathrm{~A}$ similar result was found in this study, which observed a predominance of male suicides, with aged $50-59$ years (82.19\%), and hanging the main suicide method used (86.99\%). 
In addition to hanging, the use of firearms soon appears with $8.90 \%$ of suicide cases. Poisoning was considerably low at $2.74 \%$ and cases involving the use of white weapons accounted for $1.37 \%$. According to the Brazilian Ministry of Health, the most commonly used suicide method among men is the use of firearms (44\%) and hanging $(41 \%)$ among women. ${ }^{22}$ A survey conducted in the state of Rio Grande do Sul, however, points to hanging as responsible for $62 \%$ of deaths in general. ${ }^{23}$

Thus, it can be seen that in the extreme west of Santa Catarina, hanging is the most widely used method for suicide, whereas other forms, such as firearms and poisoning, present a slightly discrete participation when compared to studies already published. Studies show that in RS, firearms represent more than $20 \%$ of suicide cases, ${ }^{24}$ while the Brazilian average corresponds to $25 \%$ (24). Poisoning, on the other hand, presented rates of $31 \%$ in a survey carried out in the city of Ribeirão Preto. ${ }^{25}$

It is possible that anthropological and cultural aspects may be related to the choice of hanging as a preferred form of suicide. Studies point out that the hanging may be linked to the gaucho culture. According to these studies suicide can be considered a respectful exit for the gaucho man, who somehow had his respect/honor hurt, and the hanging would correspond to a "masculine" way of choosing death. ${ }^{26}$ As the gauchos had a great impact in the colonization of the Far West of Santa Catarina, influencing in its culture by the occupation of its settlers from the twentieth century, it becomes an anthropological explanation. The Far West of Santa Catarina and RS present a culture of a homogeneous character, even though they are separated from the administrative political point of view, thus having a repercussion in the method chosen for suicide. ${ }^{27}$

The data analyzed in this study showed a ratio of 120 men (82.19\%) to 26 women (17.81\%) in cases of suicide or approximately 4 men for each woman. These data are similar to those found in the Mortality Information System (SIM), which show that in Brazil, in the year of 2013, there were 8,309 suicides between men and 2,223 among women, that is, a proportion of approximately 4 men for each woman. ${ }^{28}$ Kaplan and Sadock also portray that men commit suicide four times more than women. Women, however, are four times more likely to try it. ${ }^{29}$

The age group with the highest number of suicides comprised 50-59 years, 40-49 years, 70-79 years, respectively. Survey rates show that suicide rates increase with age and underscore the importance of the midlife crisis. Predisposing factors such as unemployment, lack of social support, legal and financial difficulties, low literacy, stress, chronic diseases 
and psychiatric illnesses such as drug dependence and depression are associated with and usually frequent in this age group..$^{1721}$ Thus, older people attempt suicide more often than younger ones, even cases of suicide among young people presented worrying rates, ${ }^{30}$ as shown in Figure 2.

The periods of the year analyzed with the highest number of occurrences of suicide were the months of February and November, periods with high temperatures, but without great variation when compared with the other months of the year. It becomes difficult, therefore, to find a significant seasonal correlation. In previous studies, suicides increase somewhat in the spring and fall, but not during the holiday period. ${ }^{27}$ What was found were completed suicides before and after the holiday season (Figure 4).

Alcohol is a depressant psychoactive substance in the central nervous system that modifies perceptions and behaviors, which may decrease attention and increase aggressiveness. ${ }^{28}$ The results showed that $23.97 \%$ of the suicide victims analyzed in the present study presented positive blood alcohol contente and 4 people totaling $2.73 \%$ presented concentrations of ethanol higher than 30 decigrams per liter which represents an intake of 10 glasses of beer. On the other hand, in a rate of $75.34 \%$ of people who performed suicide, it was not detected alcoholic concentrations, making it difficult to suggest the existence of an association between alcohol consumption and the occurrence of suicide cases.

However, data presented by the United States Centers for Disease Control and Prevention show that $24 \%$ of suicide victims had blood alcohol content above $0.8 \mathrm{~g} / \mathrm{L}$. Thus, in cases where alcohol was used, one can believe that there was a loss of critical judgment and self-control, aiding in the predisposition to trigger suicidal behavior in those predisposed to it. ${ }^{31,32}$ In addition, $97.14 \%$ of the cases with positive blood alcohol content represent male subjects. Thus, in addition to being more susceptible to suicide, men are even more likely to use alcohol when practicing suicide.

The results on alcohol consumption by suicide victims according to the day of the week and the period of the day revealed that although the majority of suicides occurred during the daytime period (08:00 - 11:59) and at weekends (with predominance on Sunday), there was a high proportion of victims with positive blood alcohol intake during the night and on Sundays, which may be related to the greater consumption of alcohol in bars and parties, during recreation during this period, as well as the heavy use of episodic alcohol. 
The presence of benzodiazepines and antidepressants in the sample analyzed in some cases of suicide suggests and characterizes suicide as depressive, anxious and probably difficult to induce sleep. Characteristics such as these can lead to suicidal acts, since the lack of mental balance as a factor that causes psychological problems, such as depression and anxiety, interferes in the life expectancy of people, even if they present the best possibilities of a long and better life. ${ }^{4}$ Other drugs that alter the central nervous system were also detected less predominantly, being characterized as motifs or inducers of suicide.

Simon and Savarino ${ }^{33}$ compared the rate of suicide attempts in the 90 days before and 180 days after antidepressant or psychotherapy began and found that the incidence of suicide attempts in adults and in patients under 25 years of age was higher the month before starting treatment. The use of antidepressants, which do not reach therapeutic success, has already been pointed out as having a greater relation with suicide than the use of drugs. ${ }^{34}$

According to the Brazilian Psychiatric Guideline, ${ }^{35} 50 \%$ of individuals who use benzodiazepine for more than one year have an increased risk of withdrawal, accidents, overdose (especially when associated with other psychotropic drugs), suicide attempt (especially in depressive individuals), reduction in work capacity and increase in hospitalization costs, consultations and examinations. This is emphasized by Naloto, Lopes, Barberato Filho, Lopes, Del Fiol and Bergamaschi36 reported that individuals with depressive disorders should use alprazolam or diazepam cautiously because of the increased risk of mania and suicide.

Studies have shown that alcohol and cocaine / crack use is related to suicide attempts, with increased depressive symptoms and impulsivity. 37,38

\section{CONCLUSION}

The results obtained in this study reinforce the concern regarding cases of suicide and an association between alcohol/drug use and suicidal practices in the Far West of Santa Catarina. In general, most cases of suicide occurred in males, ranging in age from 50-59 years, mainly at daytime and on weekends, with hanging being the main suicide method. The use of alcohol/drugs was small but significant. 
In addition, the knowledge related to frequent indexes such as age, sex, period, time and suicidal method is expanded, providing subsidies for the elaboration and implementation of preventive actions, aiming to reduce deaths from suicidal practice.

One should discuss suicide by emphasizing the issue of prevention, since people tend to view death as the only and last solution to suffering. Also, it is important to relate the preparation of professionals and even people to the signs of suicide, so that specialized help becomes a possible option, being essential in reducing the number of deaths caused by suicide.

\section{CONFLICTS OF INTEREST}

The authors declare no conflicts of interest.

\section{CONTRIBUTORS}

All the authors had an important role in the elaboration of this article. The author Fagner Genz and Abel Petter as paper the data collection, literature review and data analysis. Meanwhile, the author Eduardo Ottobelli Chielle assisted in the elaboration of graphs, guided the elaboration of the article, analyzed the data and did the critical review of the content.

\section{ACIKNOWLEDGMENTS}

We thank the General Institute of Expertise, SC for providing the epidemiological data. The authors also thank Universidade do Oeste de Santa Catarina.

\section{REFERENCES}

1. Ramos INB, Falcão EBM. Suicide: a Little-Known Topic in Medical Training. Rev Bras

Educ Med. 2011;35(4):507-16. 
2. Organização Mundial da Saúde. Prevenção do suicídio: manual dirigido a profissionais das equipes de saúde mental. Genebra: OMS; 2006.

3. Reichenheim ME, Souza ER, Moraes CL, Mello-Jorge MHP, Silva CMFP, Souza MMC. Violence and injuries in Brazil: the effect, progress made, and challenges ahead. Lancet. 2011;377(9781):1962-75.

4. Sehnem SB, Palosqui V. Características epidemiológicas do suicídio no estado de Santa Catarina. Fractal Rev Psicol. 2014;26(2):365-78.

5. World Health Organization. Suicide data [Internet]. 2018 [cited 2018 Dec 18]. Available from: https://www.who.int/mental_health/prevention/suicide/suicideprevent/en/

6. Bahls SC, Botega NJ. Epidemiologia das tentativas de suicídio e dos suicídios. In: Mello MF, Mello AF, Kohn R, editors. Epidemiologia da saúde mental no Brasil. Porto Alegre: Artmed; 2007. p. 151-171.

7. World Health Organization. Suicide rates, by gender, Brazil; 1980-2008 [Internet]. 2013 [cited 2013 Aug 1]. Available from: https://www.who.int/mental_health/prevention/suicide/suicideprevent/en/

8. Mello-Santos C, Wang YP, Bertolote JM. Epidemiology of suicide in Brazil (19802000): characterization of age and gender rates of suicide. Rev Bras Psiquiatr. 2005;27(2):131-4.

9. Nock MK, Borges G, Bromet EJ, Cha CB, Kessler RC, Lee S. Suicide and suicide behavior. Epidemiol Rev. 2008;30:133-54.

10. D‘Oliveira CFA. Perfil epidemiológico dos suicídios. Brasil e regiões, 1996 a 2002. Ministério da Saúde [Internet]. 2005 [citado 2008 Jan 20]. Disponivel em: http://portal. saude.gov.br/portal/arquivos/pdf/Suicidios.pdf

11. Peixoto HCG. Redução da morbimortalidade por acidentes e violências: diagnóstico do problema em Santa Catarina. Secretaria Estadual de Saúde de Santa Catarina [Internet]. 2003 [citado 2008 Jan 20]. Disponivel em: www.saude.sc.gov.br/gestores/ sala_de_leitura/doc_tecnicos 
12. Schmitt R, Lang MG, Quevedo J, Colombo T. Perfil epidemiológico do suicídio no Extremo-Oeste do estado de Santa Catarina, Brasil. Rev Psiquiatr Porto Alegre. 2008;30(2).

13. Vidal CEL, Gomes CB, Mariano CA, Leite LMR, Silva RA, Lasmar SC. Perfil Epidemiológico do suicídio na microrregião de Barbacena, Minas Gerais, no período de 1997 a 2012. Cad. Saúde Colet. 2014;22(2):158-64.

14. Dahlberg LL, Biroux B, Stouthamer-Loeber M, Van Kammen WB. World report on violence and health. Geneva: World Health Organization; 2002.

15. Hawton K, Van Heeringen K. Suicide. Lancet. 2009;373(9672):1372-81.

16. Organização Mundial da Saúde. Prevenção do suicídio: um manual para médicos clínicos gerais. Genebra: Departamento de Saúde Mental, Transtornos Mentais e Comportamentais; 2000.

17. Klerman GL. Clinical epidemiology of suicide. J Clin Psychatry. 1987;48(12):33-8.

18. Pirkola SP, Isometsä ET, Heikkinen ME, Lönnqvist JK. Suicides of alcohol misusers and non-misusers in a Nationwide population. Alcohol Alcohol. 2000;35(1):70-5.

19. Fleischmann A, Bertolote JM, De Leo D, Botega N, Phillips M, Sisask M, et al. Characteristics of attempted suicides seen in emergency-care settings of general hospital in eight low- na middle-income countries. Psychol Med. 2005;35(10):1467-74.

20. Suominen K, Isometsä E, Suokas J, Haukka J, Achte K, Lönnqvist J. Completed suicide after a suicide attempt: a 37-year follow-up study. Am J Psychiatry. 2004;161(3):5623.

21. Skogman K, Alsén M, Öjehagen A. Sex differences in risk factors for suicide after attempted suicide: a follow-up study of 1052 suicide attempters. Soc Psychiatry Pschiatr Epidemiol. 2004;39(2):113-20.

22. D‘Oliveira CFA. Perfil epidemiológico dos suicídios. Brasil e regiões, 1996 a 2002. Ministério da Saúde [Internet]. 2005 [citado 2008 Jan 20]. Disponível em: http:// portal.saude.gov.br/portal/arquivos/pdf/Suicidios.pdf 
23. Meneghel SN, Victora CG, Faria NMX, Carvalho LA, Falk JW. Características epidemiológicas do suicídio no Rio Grande do Sul. Rev Saúde Pública. 2004;38(6):804-10.

24. Santos SM, Barcellos C, Carvalho MS, Flores R. Detecção de aglomerados espaciais de óbitos por causas violentas em Porto Alegre, Rio Grande do Sul, Brasil, 1996. Cad. Saúde Pública. 2001;17(5):1141-51.

25. Marin-León L, Barros MBA. Mortes por suicídio: diferenças de gênero e nível socioeconômico. Rev Saúde Pública. 2003;37(3):357-63.

26. Ministério da Saúde. Sistema de Informações sobre Mortalidade [SIM] - DATASUS [Internet]. 2018 [citado 2018 Dez 18]. Disponivel em: http://tabnet2.datasus.gov.br/ cgi/tabcgi.exe?idb2013/c09.def

27. Sadock BJ, Sadock VA. Compêndio de Psiquiatria: ciências do comportamento e psiquiatria clínica. Porto Alegre: Artmed; 2007. p. 9.

28. Leyton V, Ponce JC, Andreuccett G, Coelho CAS, Greve JMD, Sinagawa DM, et al. Mortes no trânsito relacionadas ao uso de álcool no Estado de São Paulo em 2006. Rev. Abramet. [Internet]. 2009 [citado 2018 Fev 18];27(2):26-31. Disponivel em: http://asp-br.secure-zone.net/v2/index.jsp?id=3362/3585/2946\&lng=pt_br

29. World Health Organization. World Health Statistics data visualizations dashbord [Internet]. 2018 [cited 2018 Dec 18]. Available from: http://apps.who.int/gho/data/ node.sdg.3-4-viz-2?lang=en

30. Leal OF. Suicídio, honra e masculinidade na cultura gaúcha. Cad Antropologia UFRGS. 1992;7-14.

31. Woloszyn N. Em busca da terra: colonização e exploração de madeiras no Oeste Catarinense. Universidade do Contestado [Internet]. 2008 [citado 2008 Jan 20]. Disponível em: http://www.pesquisa.uncnet.br/pdf/historia/busca_terra_colonizacao_exploracao_madeiras_oeste_catarinense.pdf

32. Ministério da Saúde divulga dados sobre casos de suicídio no Brasil. Galileu Magazine. 2018 Set 23. Disponível em: https://revistagalileu.globo.com/Ciencia/Saude/noti$\mathrm{cia} / 2018 / 09 /$ ministerio-da-saude-divulga-dados-sobre-casos-de-suicidio-no-brasil. html 
33. Simon G, Savarino J. Suicide attempts among patients starting depression treatment with medications or psychotherapy. Am J Psychiatry. 2007;164:1029-34.

34. Plewnia C, Padberg F. Transkranielle und invasive Hirnstimulationsverfahren bei Depression. Der Nervenarzt. 2012;83(8):1006-12.

35. Nastasy H, Ribeiro M, Marques ACPR. Abuso e dependência dos benzodiazepínicos. Projeto diretrizes. Rio de Janeiro: Associação Brasileira de Psiquiatria; 2008.

36. Naloto DCC, Lopes FC, Barberato Filho S, Lopes LC, Del Fiol FS, Bergamaschi CC. Prescrição de benzodiazepínicos para adultos e idosos de um ambulatório de saúde mental. Ciênc. Saúde Coletiva. 2016;21(4).

37. Conner KR, Houston RJ, Swogger MT, Conwell Y, You S, He H, et al. Stressful life events and suicidal behavior in adults with alcohol use disorders: role of event severity, timing, and type. Drug Alcohol Depend. 2012;120(1-3):15561.

38. Winhusen TM, Somoza EC, Lewis DF, Kropp FB, Horigian VE, Adinoffd B. Frontal Systems Deficits in Stimulant-Dependent Patients: evidence of Pre-illness Dysfunction and Relationship to Treatment Response. Drug Alcohol Depend. 2013;127(1-3):94100.

Recebido em: 6 de março de 2019 Avaliado em: 29 de março de 2019 (Avaliador A) Avaliado em: 25 de setembro de 2019 (Avaliador B) Aceito em: 27 de setembro de 2019 